\title{
Climate Impacts on Tree Growth in the Sierra Nevada
}

\author{
Mélaine Aubry-Kientz * (1D) and Emily V. Moran \\ School of Natural Sciences, UC Merced, Merced, CA 95343, USA; emoran5@ucmerced.edu \\ * Correspondence: melaine.aubry.kientz@gmail.com; Tel.: +1-209-631-5503
}

Received: 16 July 2017; Accepted: 26 October 2017; Published: 1 November 2017

\begin{abstract}
Rising temperatures and aridity may negatively impact tree growth, and therefore ecosystem services like carbon sequestration. In the Sierra Nevada in California, annual variation in precipitation is high, and forests have already been impacted by several recent severe droughts. In this study, we used growth census data from long-term plots in the Sierra Nevada to calibrate an annual climate-dependent growth model. Our results highlight a high diversity of responses to climate, although the effects of climate are small compared to those of tree size and competition. Some species grow less during dry years (Pinus contorta and Calocedrus decurrens) but, surprisingly, other species exhibit higher growth during dry years (Pinus monticola, Abies magnifica, Pinus jeffreyi, Quercus kelloggii). These results emphasize the need for growth models to take into account species variability, as well as spatial heterogeneity, when studying mixed conifer forests. So far, temperatures have increased in California, and tree growth of some species may drastically decrease in the Sierra Nevada if warming continues, leading to changes in forest structure and composition as well as potential changes in wood production and carbon sequestration.
\end{abstract}

Keywords: tree growth; climate; growth model

\section{Introduction}

Forest dynamics are strongly affected by climate [1-6] and, as climate continues to change, impacts on forests are likely to be profound $[7,8]$. The forests of the Sierra Nevada in California are exposed to a Mediterranean climate, with little or no precipitation during summer (June through September) [9]. Therefore, longer and drier summers can lead to severe drought. Average temperatures and precipitation patterns in California have already shifted since the beginning of the 20th century [10] and the state has experienced several severe droughts in the past 20 years [11,12]. Future climate in the Sierras is predicted to be warmer, with an average increase in annual temperature ranging from 1.35 to $2{ }^{\circ} \mathrm{C}$ by mid-century and summer temperature increases that are equal to or greater than increases in winter temperatures $[13,14]$. Precipitation predictions are variable [13-16]. For instance, projections of annual precipitation for 2060-2069 vs. 1985-1994 range from $-23 \%$ to $9 \%$ in the Sierra Nevada [13]. The increase in variability in precipitation coupled with increasing temperatures imply earlier snow melt and altered water availability $[13,17,18]$ that will impact forest dynamics.

Tree growth provides an important climate change feedback, as it affects carbon sequestration in wood and therefore can alter carbon cycle and storage [19]. Growth is also an indicator of overall tree vigor, and is often a good predictor of mortality [20]. Trees exhibiting a history of below-average growth or abrupt decreases in growth have higher mortality [21-23]. It is thus crucial to better understand tree growth, especially as it relates to climate. Severe droughts can lead to declines in tree growth and elevated mortality [24-29]. Because tree species often respond in distinct ways to climate, climate change is likely to shift patterns of relative abundance within forests [4,6,26,30-33].

Tree growth varies considerably from year to year, and this is often correlated with climatic variations [30]. Studies of annual growth variation in relation to climate are mostly based on dendrochronological (tree ring) data [4,30,34-36]. In the Sierra Nevada, such studies have 
found that more precipitation is usually beneficial to growth and that higher winter minimum temperatures tend to be beneficial while higher summer maximum temperatures tend to be detrimental [37,38]. Moreover, species-specific relationships were often found between tree growth and climate variability [37-39].

Forest inventory data can also help us in identifying growth drivers [40,41]. Inventory data includes all the trees in a stand, while dendrochronological studies have traditionally targeted trees that are expected to be sensitive to climate, which can introduce bias [42]. Two recent studies in the Sierra Nevada for instance, focused on big trees due to their expected sensitivity [38,39]. Moreover, competitive environment can affect growth as strongly as climate, or more so [39]. Because trees in regularly censused plots are mapped, one can take into account the effect of competition by calculating neighborhood basal area or competition indices for every tree [43]. In addition, inventory data is increasingly available for a wide variety of forests [44]. However, the inventories may not occur on an annual basis, so we need appropriate inference models to fit annual growth [44]. Ideally, increment core data and diameter measurements would be incorporated into the same model; this approach has been shown to decrease parameter uncertainty $[43,45]$. However, tree cores and diameter measurements are not always available for the same sites.

In this paper, we used measurements of tree diameters from 26 plots in the Sierra Nevada to (1) build a species-specific annual growth model accounting for tree size and inter-tree competition, (2) identify the climate effects on tree growth, and (3) compare these effects across species. Our results add to the understanding of climate-growth relationships and therefore can enhance predictions of the impacts of global climate change on forests in the Sierra Nevada. Moreover, growth predictions derived from our model can be integrated within individual-based dynamic models to better model individual growth variability and investigate tree population dynamics under varying climatic conditions.

\section{Material and Methods}

\subsection{Data}

The study was conducted using data collected by the USGS from 26 long-term plots in Sequoia-Kings Canyon National Park and Yosemite National Park (Table 1). The plots are at elevations from 1500 to $3097 \mathrm{~m}$. Plot sizes ranged from 0.9 to 2.5 hectares, with most being 1 ha. These plots were established between 1982 and 2001 to improve mechanistic understanding of forest dynamics and to detect and interpret long-term changes in forest structure and dynamics and effects of fire on these variables.

Twelve tree species occur within these plots (Table 2). However, two species were omitted from the analysis because they were too rare (Pseudotsuga menzeisii) or diameter measurements were too error-prone due to trunk size and structure (Sequoiadendron giganteum). Trees were individually tagged, and diameter at breast height (DBH) was measured every 4 to 6 years between the establishment of the plot and 2015. Most of the intervals between measurement are 5 years long, but some intervals vary due to constraints of funding, workload, and weather (Figure A1). No increment cores have been collected due to concerns from the original research team about influencing tree mortality. 
Table 1. Plot description: name of the plot, elevation above sea level in meters, size in hectares, basal area at the establishment of the plot in $\mathrm{m}^{2}$, establishment year, and dominant species (those that make up more than $20 \%$ of the stand, species abbreviations given in Table 2).

\begin{tabular}{cccccc}
\hline Name & Elev $(\mathbf{m})$ & Size $(\mathbf{h a})$ & $\left.\mathbf{B A} \mathbf{( m}^{\mathbf{2}}\right)$ & Est & Dominant Species \\
\hline YOHOPIPO & 1500 & 1 & 67.1 & 1991 & ABCO, CADE, PILA \\
BBBPIPO & 1609 & 1 & 68.8 & 1992 & CADE, QUKE \\
CCRPIPO & 1637 & 1.1 & 70.6 & 1991 & CADE, ABCO \\
CRCRPIPO & 1637 & 1 & 71.1 & 1993 & ABCO, CADE \\
FFS7CONTROL & 1941 & 1 & 80.2 & 2001 & ABCO, PILA, CADE \\
FFS6BURN & 2018 & 1 & 50.6 & 2001 & ABCO, PILA \\
FFS5BURN & 2030 & 1 & 78.8 & 2001 & ABCO, CADE \\
SURIP & 2033 & 1.4 & 90.7 & 1982 & ABCO \\
SUABCO & 2035 & 0.9 & 64 & 1983 & ABCO, CADE \\
SUPILA & 2059 & 1.1 & 74.1 & 1983 & ABCO \\
FRPIJE & 2106 & 1 & 19.4 & 1983 & PIJ, QUKE \\
FFS2BURN & 2128 & 1 & 75.9 & 2001 & ABCO, ABMA \\
LMCC & 2128 & 2 & 319.3 & 1982 & ABCO, ABMA \\
LOTHAR & 2167 & 1.1 & 85.9 & 1984 & ABCO \\
LOGSEGI & 2170 & 2.5 & 362.1 & 1983 & ABCO \\
UPTHAR & 2202 & 1 & 81.2 & 1984 & ABCO \\
LOLOG & 2207 & 1.1 & 70 & 1985 & ABCO, ABMA \\
UPLOG & 2210 & 1 & 54.1 & 1985 & ABCO \\
LOGPIJE & 2405 & 1 & 18.3 & 1985 & ABCO, PIJE \\
SFTRABMA & 2484 & 1 & 100.6 & 1992 & ABMA \\
WTABMA & 2521 & 1 & 56.9 & 1993 & ABMA \\
POFLABMA & 2542 & 1 & 105.9 & 1994 & ABMA \\
PGABMA & 2576 & 1 & 96.9 & 1992 & ABMA \\
EMSALIX & 2838 & 1 & 2.5 & 1983 & PIMO, PICO \\
EMSLOPE & 2950 & 1 & 19.7 & 1983 & PIMO \\
EMRIDGE & 3097 & 1.1 & 16.2 & 1984 & PIMO \\
\hline
\end{tabular}

Table 2. Species: scientific name, common name, code used throughout the article, total number of trees, and average annual growth rate in $\mathrm{cm}$. The average annual growth rate is computed by dividing the total growth during an interval by the number of years.

\begin{tabular}{ccccc}
\hline Species Name & Common Name & Code & Number of Trees & $\begin{array}{c}\text { Annual Growth } \\
\text { Rate (cm) }\end{array}$ \\
\hline Abies concolor & White fir & ABCO & 6919 & 0.22 \\
Abies magnifica & Red fir & ABMA & 4663 & 0.17 \\
Pinus contorta & Lodgepole pine & PICO & 68 & 0.20 \\
Pinus jeffreyi & Jeffrey pine & PIJE & 282 & 0.20 \\
Pinus monticola & Western white pine & PIMO & 382 & 0.28 \\
Pinus lambertiana & Sugar pine & PILA & 2798 & 0.19 \\
Pinus ponderosa & Ponderosa pine & PIPO & 564 & 0.17 \\
Calocedrus decurrens & Incense cedar & CADE & 4821 & 0.15 \\
Quercus chysolepis & Canyon live oak & QUCH & 75 & 0.082 \\
Quercus kelloggii & Black oak & QUKE & 1274 & 0.12 \\
\hline
\end{tabular}

Different climate variables are expected to affect tree growth in distinct ways. Given the relatively dry climate, we expected tree growth to be higher when water availability is higher $[4,24,26,46]$. Raw precipitation or amount of snow provide an estimate of the total amount of water received during the wet season. April snowpack gives an estimation of the water stock at the end of the wet season that has not yet been released to the soil [28]. Areas where the majority of precipitation falls as rain also have high evaporative water demand due to warmer temperatures [35]. Climatic water deficit (CWD), which is defined as potential evapotranspiration minus actual evapotranspiration (AET), reflects this interaction between water availability and temperature. Very low or high temperatures can also affect 
tree growth directly. The eight climate variables examined in this study are taken from CA BCM model downscaling. This model downscales PRISM data to $270 \mathrm{~m}$, which is more relevant for tree responses [47] (Table 3). The actual evapotranspiration (AET) is calculated by the BCM model from the available water in the soil profile, using informations on topography, soils, and underlying geology. The potential evapotranspiration (PET) is calculated based on solar radiation and air temperature [47]. The CWD is then calculated as the difference between PET and AET.

Table 3. Description of the climate variables: name used in this study, description of the variable, unit, mean and standard deviation across the plots and years.

\begin{tabular}{ccccc}
\hline Climate Variable Name & Description & Unit & Mean Value & Standard Deviation \\
\hline AvTemp & average temperature & ${ }^{\circ} \mathrm{C}$ & 7.15 & 2.15 \\
JanMin & minimum temperature in January & ${ }^{\circ} \mathrm{C}$ & -5.22 & 2.79 \\
JulMax & maximum temperature in July & ${ }^{\circ} \mathrm{C}$ & 19.26 & 3.28 \\
precip & total annual rain precipitation & $\mathrm{mm}$ & 1190.72 & 481.82 \\
snow & total annual snowfall & $\mathrm{mm}$ & 797.77 & 415.99 \\
ASpck & April snowpack depth & $\mathrm{mm}$ & 403.79 & 469.44 \\
CWD & climatic water deficit & $\mathrm{mm}$ & 492.42 & 157.42 \\
AET & actual evapotranspiration & $\mathrm{mm}$ & 363.69 & 90.66 \\
\hline
\end{tabular}

At these sites in the southern Sierra Nevada, average temperature both within seasons and over the whole year, is highly negatively correlated with elevation. Annual precipitation and climatic water deficit, on the other hand, are highly variable from year to year and poorly correlated with elevation. Precipitation as snow is intermediate, being moderately positively correlated with elevation. Annual deviation of the climate variables from plot means are not correlated with elevation.

\subsection{Simulated Dataset}

\subsubsection{Testing the Effect of Different Observation Time Intervals}

The model used in this paper is based on a method developed by Eitzel et al. [44] to parametrize a model of annual tree growth with non-annual data. This is possible because the model can access information from many trees experiencing many different combinations of environmental conditions. The approach of modeling annual growth as a latent (unobserved) state allows for a more realistic analysis of climate-growth effects than assuming that annual growth within a measurement period is equal. Models that include both diameter and increment data have found that, while increment data does improve estimates of annual growth for individual trees, reasonably short diameter measurement intervals can also yield good estimates [45]. To verify that it is possible to use this method to identify annual climate variables relevant for growth using this dataset, we first used the estimation algorithm with a simulated dataset and different growth measurement intervals.

The simulated dataset consists of 1000 trees, with initial diameters drawn from a normal distribution with a mean of 50 and with standard deviation 15 . We simulated annual average temperature data for a 25-year period by drawing from a normal distribution with mean 7 and standard deviation 2.5. The diameter increment of each tree is computed as a linear function of diameter and the simulated climate variable: $\delta D B H=\beta_{0}+\beta_{1} \times D B H+\beta_{2} \times A v$ Temp. The parameters used are $\beta_{0}=2, \beta_{1}=0.02, \beta_{2}=1.5$. Estimation of $\beta_{2}$, the parameter linking growth to average temperature is plotted in Figure 1, with seven different measurement intervals ranging from one to seven years. Parameter estimation was highly accurate for intervals of four years or less, and moderately accurate for intervals of 5-6 years. For a measurement interval of 7 years, the standard deviation of the estimated parameter abruptly increases. Therefore we do not recommend this inventory-data-only method to be used for datasets with measurement intervals of $>6$ years (e.g., FIA data). 


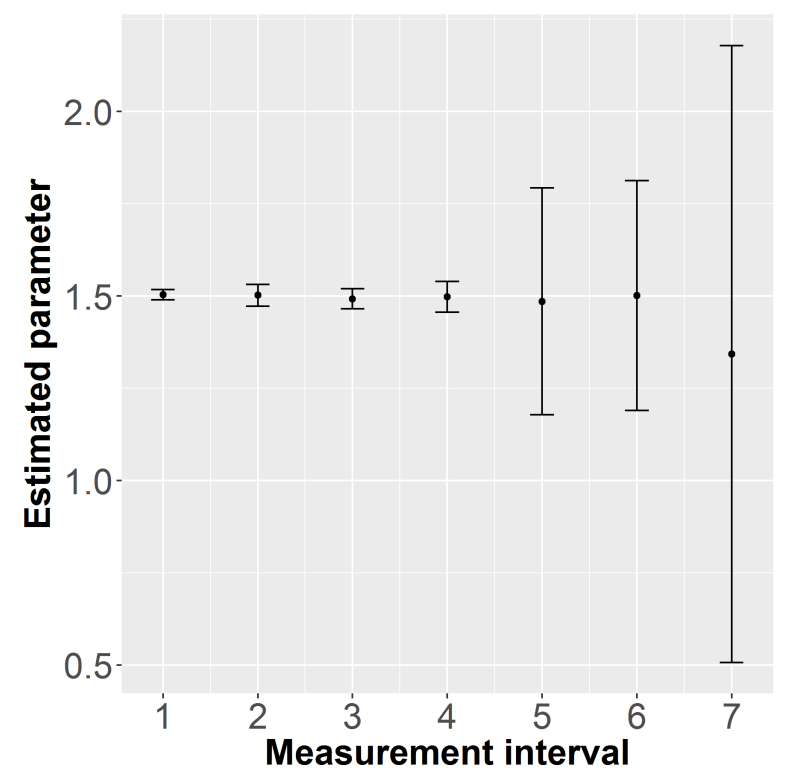

Figure 1. Estimated parameters, with standard deviation, plotted against the observation timestep (number of years between two measurements).

\subsubsection{Testing the Ability to Detect Subtle Climate Effects}

This simulation was based on the real white firs in our dataset. The initial diameters are the first measured DBH for all white firs. Growth is computed as a function of DBH and real annual average temperature (AvTemp), with the same equation as the previous test. We used three different "true" values of the climate response parameter, ranging from -0.01 to -0.0001 . The "true" parameter values for all three trials were within the $90 \%$ confidence interval of the estimated value (Table 4 ) showing that even subtle climate effects can be detected, at least in this three-parameters version of the model.

Table 4. Results of estimation using simulated dataset. Parameter used to model the dataset (parameter value), median and $90 \%$ confidence interval of the estimated parameter.

\begin{tabular}{cccc}
\hline Parameter & $\boldsymbol{\beta}_{\mathbf{0}}$ & $\boldsymbol{\beta}_{\mathbf{1}}$ & $\boldsymbol{\beta}_{\mathbf{2}}$ \\
\hline Parameter value & 0.28 & 0.002 & -0.01 \\
Parameter estimation & 0.287 & 0.00183 & -0.01020 \\
& {$[0.276 ; 0.294]$} & {$[0.00178 ; 0.00189]$} & {$[-0.01110 ;-0.00898]$} \\
\hline Parameter value & 0.28 & 0.002 & -0.001 \\
Parameter estimation & 0.286 & 0.00183 & $-1.07 \mathrm{e}-03$ \\
& {$[0.277 ; 0.296]$} & {$[0.00175 ; 0.00188]$} & {$[-2.26 \mathrm{e}-03 ; 6.62 \mathrm{e}-05]$} \\
\hline Parameter value & 0.28 & 0.002 & -0.0001 \\
Parameter estimation & 0.286 & 0.00182 & $-5.37 \mathrm{e}-05$ \\
& {$[0.277 ; 0.297]$} & {$[0.00176 ; 0.00188]$} & {$[-1.26 \mathrm{e}-03 ; 9.76 \mathrm{e}-04]$} \\
\hline
\end{tabular}

\subsection{Model}

The model estimates annual tree growth from forest inventory data with a Bayesian framework. An observation process is added with an observation error $\sigma_{o b s}^{2}$. Figure 2 shows the hierarchical structure of the model described by Equations (1) and (2). 


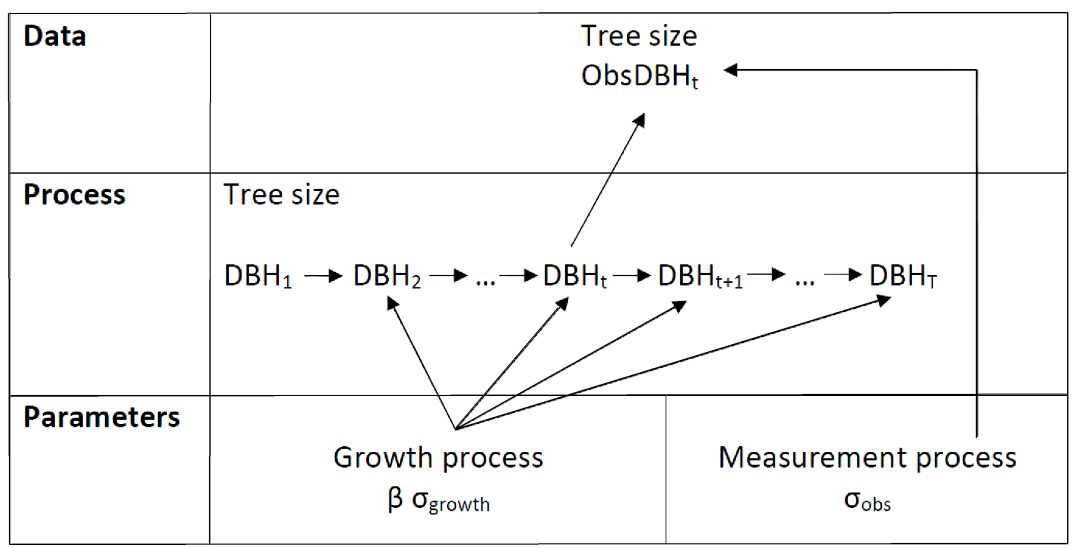

Figure 2. Model structure. Parameters of the growth process are used to model annual growth every year. When the tree is measured an additional measurement process is used to estimate the observed diameter.

$$
O b s D B H_{i, t} \sim \mathcal{N}\left(D_{i, t}, \sigma_{o b s}^{2}\right)
$$

where $O b s D B H_{i, t}$ is the observed DBH of tree $i$ at time $t$ and $D_{i, t}$ is the DBH of tree $i$ at year $t$.

Tree DBH increment is modeled as a linear function of the current $\mathrm{DBH}$, competition, and the climate variables. The intercept is species-specific to allow for variation growth between species. The climate effect parameter is also species-specific. The focus on diameter increment rather than diameter itself as in Eitzel et al. was inspired by Clark et al. [44,45].

$$
\begin{array}{r}
D_{i, t}=D_{i, t-1}+\Delta D_{i, t-1} \\
\Delta D_{i, t} \sim \mathcal{N}\left(\beta_{0, s}+\beta_{1} \cdot D_{i, t}+\beta_{2} \cdot \sum_{j=1}^{N_{i, t}} \frac{D_{j, t}}{\text { dist }_{i, j}}+\beta_{3, s} \cdot \operatorname{clim}_{t}, \sigma_{\text {growth }}^{2}\right) \\
\text { with } \Delta D_{i, t} \geq 0
\end{array}
$$

where $\Delta D_{i, t}$ is the DBH increment of tree $i$ of species $s$ between year $t$ and $t+1, N_{i, t}$ is the number of trees that are closer than $10 \mathrm{~m}$ from tree $i$ at year $t, D_{j, t}$ is the DBH of neighbor $j$ at year $t$, dist $_{i, j}$ is the distance between tree $i$ and its neighbor $j, \operatorname{clim}_{t}$ is the climatic variable of interest during year $t$, $\beta_{0,1,2,3}$ are estimated, and $\sigma_{\text {growth }}^{2}$ is the error of the growth model (also estimated). Tree DBH increment is drawn from a truncated normal distribution to make sure that growth $\Delta D_{i, t}$ is positive. Years are water years, starting on 1 October of the preceding calendar year, marking the beginning of the rainy season in California, and ending in September of the corresponding calendar year.

To model competition, we used the Heygi index, which is the neighbor's diameter divided by the distance to the targeted tree summed over all neighbors: $\sum_{j=1}^{N_{i, t}} \frac{D_{j, t}}{\text { dist }_{i, j}}[40,41,48-51]$. This competition index was correlated with tree growth in other studies in the same geographic area $[40,52,53]$. The prior mean for the measurement error standard deviation $\left(\sigma_{o b s}^{2}\right)$ is 0.52 , based on a re-measurement of all trees of one of the plots (LOLOG, 2002). All other priors are non informative, we used a uniform prior for $\sigma_{\text {growth }}^{2}$ and a normal prior for $\beta_{0,1,2,3}$.

The effects of current diameter and competition may vary from one species to another. A first model selection, without climate variable s, was performed using the Deviance Information Criterion (DIC) to identify which variables have to be species-specific. Results suggested that model performance was best when the intercept (mean growth) was species-specific but the diameter and competition effects were not (Table A1).

We then added to this model a single climate effect. We parameterized this model using all climate variables from both the current and past year, because there may be lag effects in climate 
responses [54,55]. In addition to examining both current and past climate, we parameterized one version of the model using raw climate variables, and another version using the deviation from the 30-year mean climate of the plot, allowing us to disentangle the effects of annual variation from effects of, for example, hot or cold conditions per se.

DIC was computed for all models in order to compare fit. The final model has been created using a systematic forward approach based on the DIC. We added variables to the model one at a time. At each step, each variable that is not already in the model is tested for inclusion in the model. The most significant of these variables is added to the model, so long as it reduces the DIC of the model. The parametrization was performed using WinBugs, R [56], and the R-package R2WinBugs [57].

\section{Results}

Most climate variables have an effect on growth for most species when they are introduced separately into the model (Table 5, see Tables A3 and A4 for details). We considered that the climate variable had an impact on growth when the $95 \%$ confidence interval of parameter $\beta_{3}$ of Equation (2) did not overlap zero.

Table 5. Effect of the climate variable on tree growth. $\downarrow$ when the $95 \%$ confidence interval of the parameter is negative, $\uparrow$ when the $95 \%$ confidence interval of the parameter is positive, and nothing when 0 is in the $95 \%$ confidence interval of the parameter.

\begin{tabular}{|c|c|c|c|c|c|c|c|c|c|c|}
\hline & PIMO & PICO & ABMA & PIJE & ABCO & QUKE & QUCH & PILA & CADE & PIPO \\
\hline $\mathrm{AvTemp}_{t}$ & & $\downarrow$ & $\uparrow$ & $\uparrow$ & $\uparrow$ & $\uparrow$ & $\downarrow$ & $\uparrow$ & & $\downarrow$ \\
\hline $\operatorname{JanMin}_{t}$ & & $\downarrow$ & & $\uparrow$ & $\uparrow$ & $\uparrow$ & $\downarrow$ & & $\downarrow$ & $\downarrow$ \\
\hline $\operatorname{JulMax}_{t}$ & & $\downarrow$ & $\uparrow$ & & & $\uparrow$ & & & & $\uparrow$ \\
\hline $\operatorname{precip}_{t}$ & & & & & & $\downarrow$ & & & $\uparrow$ & \\
\hline snow $_{t}$ & & & $\downarrow$ & & & $\downarrow$ & & & $\uparrow$ & $\uparrow$ \\
\hline $\mathrm{CWD}_{t}$ & $\uparrow$ & $\downarrow$ & $\uparrow$ & $\uparrow$ & & $\uparrow$ & & & $\downarrow$ & \\
\hline $\mathrm{AET}_{t}$ & $\downarrow$ & & $\uparrow$ & & & $\uparrow$ & $\downarrow$ & & & \\
\hline $\mathrm{ASpck}_{t}$ & & & $\downarrow$ & & & $\downarrow$ & & $\uparrow$ & & \\
\hline $\mathrm{AvTemp}_{d e v, t}$ & $\uparrow$ & & & $\uparrow$ & & & & & $\downarrow$ & $\downarrow$ \\
\hline $\operatorname{JanMin}_{d e v, t}$ & & $\downarrow$ & $\downarrow$ & $\uparrow$ & $\uparrow$ & & $\downarrow$ & & & \\
\hline $\begin{array}{l}\text { JulMax }_{d e v, t} \\
\text { precip }_{d x \vartheta}\end{array}$ & & & & & & & $\uparrow$ & & $\downarrow$ & \\
\hline $\begin{array}{l}\text { precip }_{d e v, t} \\
\text { snow }_{d e v, t}\end{array}$ & & & $\uparrow$ & & & $\uparrow$ & & & $\uparrow$ & $\begin{array}{l}\uparrow \\
\uparrow\end{array}$ \\
\hline $\mathrm{CWD}_{d e v, t}$ & $\uparrow$ & & & $\uparrow$ & & $\downarrow$ & $\uparrow$ & & & \\
\hline $\mathrm{AET}_{d e v, t}$ & & & & & & $\uparrow$ & $\downarrow$ & & & \\
\hline $\mathrm{ASpck}_{d e v, t}$ & $\uparrow$ & & & & $\uparrow$ & $\downarrow$ & & & & \\
\hline AvTemp $_{t-1}$ & $\uparrow$ & $\downarrow$ & $\uparrow$ & $\uparrow$ & $\uparrow$ & $\uparrow$ & & & $\downarrow$ & $\downarrow$ \\
\hline $\operatorname{JanMin}_{t-1}$ & & $\downarrow$ & $\uparrow$ & $\uparrow$ & $\uparrow$ & $\uparrow$ & & & $\downarrow$ & $\downarrow$ \\
\hline $\operatorname{JulMax}_{t-1}$ & & $\downarrow$ & $\uparrow$ & & & $\uparrow$ & & & & $\uparrow$ \\
\hline $\operatorname{precip}_{t-1}$ & & & & & $\uparrow$ & $\downarrow$ & & & $\uparrow$ & \\
\hline snow $_{t-1}$ & & & $\downarrow$ & & & $\downarrow$ & & & $\uparrow$ & $\uparrow$ \\
\hline $\mathrm{CWD}_{t-1}$ & $\uparrow$ & $\downarrow$ & $\uparrow$ & $\uparrow$ & & $\uparrow$ & & & & \\
\hline $\mathrm{AET}_{t-1}$ & $\downarrow$ & & $\uparrow$ & & & $\uparrow$ & & & & $\downarrow$ \\
\hline $\mathrm{ASpck}_{t-1}$ & & & $\downarrow$ & & & $\downarrow$ & & $\uparrow$ & & \\
\hline $\mathrm{AvTemp}_{d e v, t-1}$ & $\uparrow$ & & $\downarrow$ & $\uparrow$ & & & & & $\downarrow$ & \\
\hline $\operatorname{JanMin}_{d e v, t-1}$ & & $\downarrow$ & $\downarrow$ & $\uparrow$ & $\uparrow$ & & $\downarrow$ & & & \\
\hline $\operatorname{JulMax}_{d e v, t-1}$ & & & & & $\downarrow$ & & $\uparrow$ & & $\downarrow$ & \\
\hline precip $_{d e v, t-1}$ & & & $\uparrow$ & & $\uparrow$ & & & & & \\
\hline snow $_{d e v, t-1}$ & & & $\uparrow$ & & $\uparrow$ & & & & $\uparrow$ & \\
\hline $\mathrm{CWD}_{\text {dev }, t-1}$ & $\uparrow$ & & $\downarrow$ & $\uparrow$ & $\downarrow$ & $\downarrow$ & & & & \\
\hline $\mathrm{AET}_{d e v, t-1}$ & $\downarrow$ & & & $\downarrow$ & $\uparrow$ & $\uparrow$ & & & & \\
\hline $\mathrm{ASpck}_{d e v, t-1}$ & & & & & $\uparrow$ & & & $\uparrow$ & & \\
\hline
\end{tabular}


DIC values identified average temperature of the previous year as the best predictor of growth (lowest DIC, Table A2). This variable has a mostly positive effect on growth (PIMO, ABMA, PIJE, ABCO and QUKE), although PICO, CADE and PIPO exhibited negative responses (Table 5). CWD deviation of current year also performed well, and surprisingly it has a positive effect on growth for three species (PIMO, PIJE and QUCH) and a negative effect on growth for only one species (QUKE). Other good predictors include current year snow, April snowpack deviation of previous year, snow deviation of previous year, and January minimum temperature deviation of current year (Table A2).

The final model includes average temperature of previous year, snow deviation of current year, precipitation of current year and CWD deviation of previous year (Table A5). The parameter linking growth to the current $\mathrm{DBH}\left(\beta_{1}\right)$ is positive (Table A5). This is not surprising, as diameter growth is expected to increase with tree size until leveling off or even sometimes decreasing for the largest trees [40], and most of the trees observed in this study have small DBH (mean $20 \mathrm{~cm}$ ). The parameter linking growth to the competition index $\left(\beta_{2}\right)$ is negative (Table A5), confirming that growth declines with increasing crowding $[40,41]$. The average temperature of previous year has a negative effect on growth of PICO, QUCH, PILA, CADE and PIPO, but a positive effect on growth of ABMA and QUKE. Snow deviation of current year has a positive effect on growth for ABMA, ABCO, QUKE, PILA and CADE. Precipitation of current year has a negative effect on growth for ABMA, QUKE, PILA and CADE. Finally, CWD deviation of previous year has a positive effect on growth for PIMO, PIJE and $\mathrm{QUCH}$, but a negative effect for ABCO. The two parameters accounting for the errors have similar average values (Table A5). Examples of the resulting latent variables (unobserved diameter) along with its uncertainty for trees from the four most common species are presented in Figure 3.
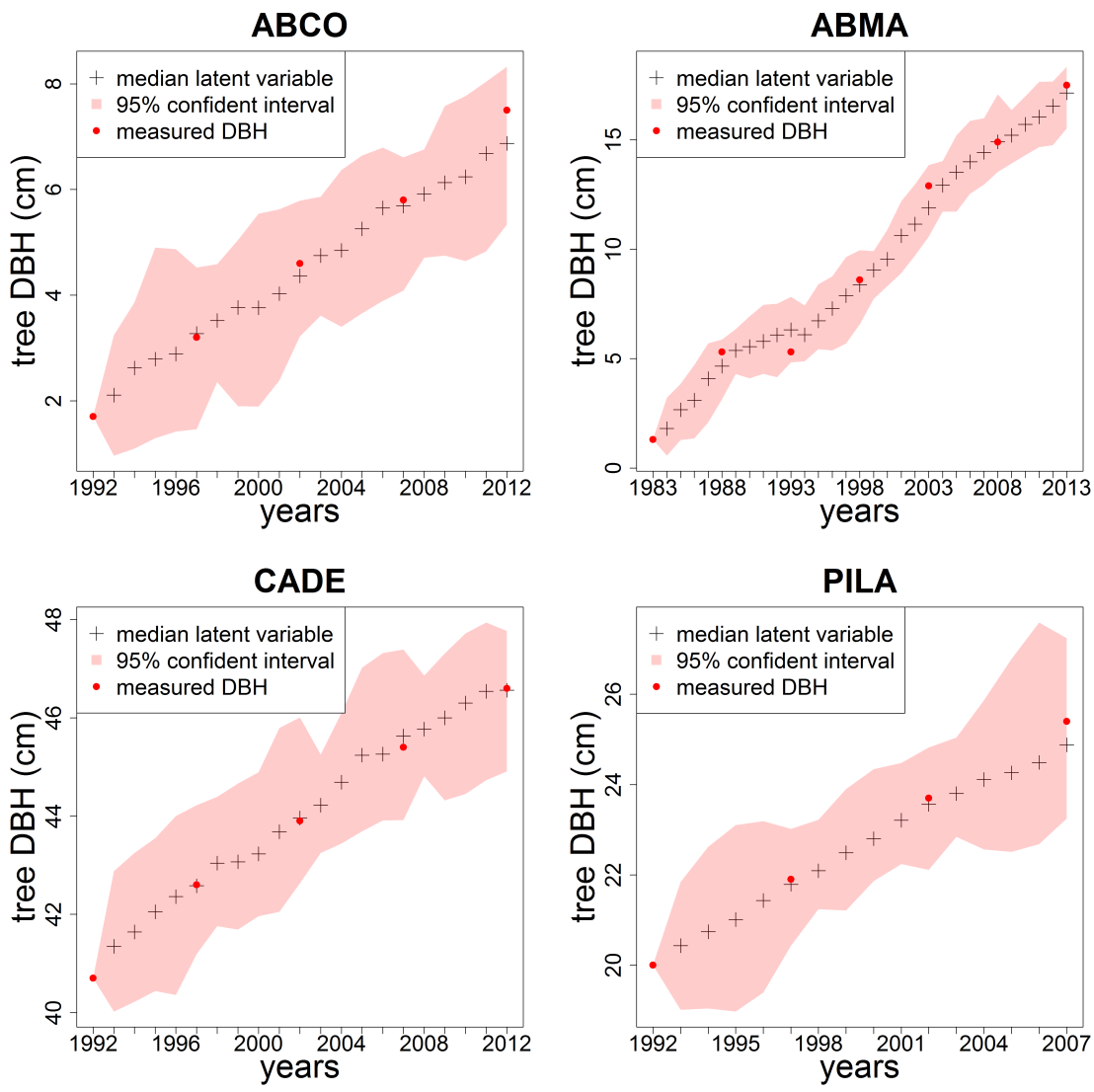

Figure 3. Latent state (tree size) is computed by the model (plotted as crosses, with uncertainty in red). Example for one tree of each of the four most common species: white fir (ABCO), red fir (ABMA), incense cedar (CADE) and sugar pine (PILA). 


\section{Discussion}

\subsection{The Growth Model}

The use of a Bayesian framework with a latent variable allows us to infer the unmeasured annual growth for a dataset with roughly 5 year measurement intervals [44] (Figure 3). Our study provides new information about the relationship between annual tree growth and climate because previous dendrochronological studies in the Sierra Nevada have focused on fewer species (3-5) and diameter classes [37-39,58]. However, some results can vary from one version of the model to another for some species.

The model accounts for a growth error $\left(\sigma_{\text {growth }}\right)$ and a measurement error $\left(\sigma_{o b s}\right)$. As suggested by Eitzel et al., we used an informative prior based on tree re-measurements to ensure a minimum amount of observation error. The estimate of the measurement error is larger than the prior mean [44].

\subsection{Growth Response to Climate}

Our results show a great diversity of responses to climate variation depending on the species. Higher snow deviation, for instance, increases growth for four species found at lower elevations (ABCO, QUKE, PILA and CADE), where precipitation, especially as snow, is low and evaporative demand is high (Figure 4). Higher average temperature of previous year decreases growth for trees found at low elevations (QUCH, PILA, CADE and PIPO), while it increases growth for ABMA and QUKE found at higher elevations (Figure 4). Trees in low and dry areas mostly obtain their water from rain and experience more drought stress during hot summer [33].
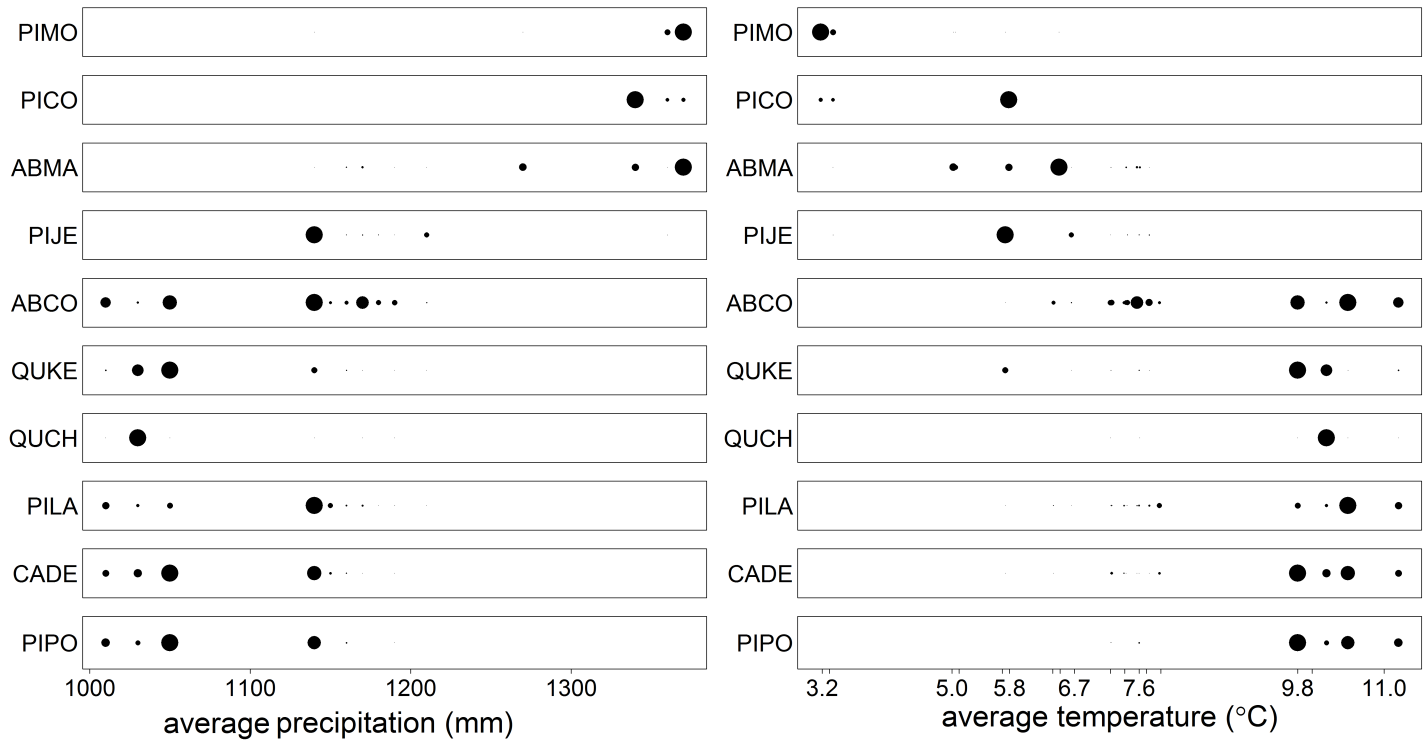

Figure 4. Range of plot average precipitation and temperature for the different species. Presence of trees for each species and each value of precipitation (left) and average temperature (right). The point sizes are proportional to the abundance of the species in the relevant plot.

Moreover, average temperature of the previous year, identified as the best predictor of growth (smallest DIC, Table A2), tends to increase growth for species found at higher elevations (PIMO, ABMA, PIJE, ABCO and QUKE) and to decrease growth for species found at lower elevations (CADE and PIPO). The exception to this pattern is PICO, a species found at high elevations, which exhibits lower growth after year with higher average temperature.

Although mean temperature or total amount of precipitation are easy to measure, variables like climatic water deficit (CWD) and actual evapotranspiration (AET) should be better predictors 
of tree growth because they reflect the effect of temperature on evapotranspiration. AET is higher in warm, wet conditions favorable for plant growth, while CWD is related to the magnitude and length of drought stress experienced by plants [59]. CWD was identified as a better predictor of growth than AET (based on DIC, Table A2; CWD deviation of previous year is included in the final model). However, the CWD effect tends to be small, and we did not observe a strong detrimental effect of higher CWD on growth as previous studies did [37-39]. For some species, growth is even enhanced when raw CWD is high (PIMO, ABMA, PIJE and QUKE) or in years where CWD deviates from the plot mean (PIMO, PIJE and QUCH). CWD may not be the best estimate of water available for trees, or the soil layer of the BCM model may be too coarse to accurately model CWD at the plot level. Other climate variables, like precipitation or snow perform better. Snow deviation and precipitation of current year are included in the final model, they are respectively second and third best predictor of growth according to the forward selection. The model finds that snow deviation is a good predictor of and enhance d growth for five species. Indeed, precipitation occurs mainly in winter in the Mediterranean climate of the Sierra Nevada and snow is an important determinant of summer water availability [60]. On the other hand, precipitation of current year surprisingly decreased growth for four species (ABMA, QUKE, PILA and CADE). This can be due to correlation between precipitation and snow, because precipitation had little effect when it was included as a single variable (Table A3).

Previous studies identified higher minimum winter temperature as beneficial for tree growth $[39,58]$, which is not what our results suggest for all species. Indeed, although three species exhibit higher growth during years with higher minimum January temperature (PIJE, ABCO and QUKE), five species exhibit lower growth (PICO, QUCH, CADE and PIPO). This might be due to milder winters leading to more rapid snowmelt, higher metabolic rates during winter, higher survival of pests and pathogens, or some combination of these factors [61-63]. Trees examined in this study are found at a wide range of elevation $(1500$ to $3097 \mathrm{~m})$ in the Southern Sierra Nevada, while previous studies focused primarily on trees at lower elevation in the Northern part of the Sierra Nevada [39,58], so the factors limiting growth may be different.

\subsection{Consequences in the Sierra Nevada}

Temperatures in the Sierra are expected to rise during the next century and precipitation patterns may shift [14]. Our results suggest a diversity of growth responses to climate change across species and sites. Different strategies can be used to better understand what these impacts will be. Dynamic vegetation models predict a greater coverage of mixed evergreen forest (a diverse low-elevation vegetation type in which oaks are an important component) along the western slope of the Sierra Nevada for the next century [32]. The tree growth model CACTOS has been used to study the potential future of tree growth under climate change $[8,26]$, showing a reduction of conifer growth during the next century, mostly driven by increased summer temperature. While the direction of precipitation change is not clear, warming in all seasons is expected, which will likely increase CWD, and decrease the amount of precipitation received as snow. According to our final model, growth is therefore likely to decrease for PILA and CADE, which have a negative response to previous year temperature and a positive response to snow deviation. On the other hand, the growth response of species such as QUKE and ABMA, which showed a positive response to both previous year temperature and snow deviation, but a negative response to total precipitation might be more sensitive to the exact degree of change in these different variables (Figure A2).

Tree growth changes resulting from climate change can lead to reduced wood production and carbon storage, and will potentially weaken the carbon sink potential in this mixed-conifer forest $[8,64]$. Moreover, if fire exclusion continues, competition could increase. Forest thinning or prescribed burning can reduce competition and offset climate effects [65], but may not be enough if climate stresses interact with insects and pathogens dynamics [66]. Our results suggest a variety of responses to climate variables among species, including some delayed responses. The legacy effect of drought 
on tree growth is higher for pines than for oaks and may impact tree carbon sequestration under climate change [54].

Growth is not the only process impacted by climate. Tree mortality will likely be enhanced by climate change $[25,67,68]$. Growth and mortality processes are intimately related to each other: trees exhibiting below-average growth or abrupt decreases in growth have higher mortality [21-23], and tree growth can be seen as an indicator of a tree's health or vigor. Tree growth is therefore often used as a predictor of tree mortality [20,69], and the climate variable impacting tree growth could have an indirect effect on mortality too. Therefore, additional investigation into the effect of climate on regeneration and mortality is also needed to better project how management actions and climate will interact in the future [64].

\section{Conclusions}

This study has shown that non-annual data can be used to study annual tree growth and to link it to climate variability. We observed a great diversity of response to climate depending on the species. We identified four climatic variables as good predictors of tree growth: average temperature of previous year, total annual snowfall deviation of current year, total precipitation of current year, and CWD deviation of previous year. Species found at lower elevations mostly have lower growth after warm years and higher growth during years with more snow, while species found at higher elevations exhibit the opposite pattern. The effects of precipitation and CWD are surprising: precipitation tends to reduce growth for four species and CWD tends to enhance growth for three species. Our results suggest that effects of multiple climatic factors, the magnitude of shifts in climate relative to species-level tolerances, and limiting factors such as competition should be taken into account when projecting the effects of climate change on forest growth and dynamics.

Acknowledgments: We thank Adrian Das and Nathan Stephenson of the US Geological Survey for supplying the data, and Adrian Das, Jeffrey Lauder and three anonymous reviewers for helpful suggestions on the manuscript. Funding came from UC Merced.

Author Contributions: M.A.-K. and E.V.M. conceived and designed the models; M.A.-K. performed the models; M.A.-K. and E.V.M. analyzed the data; M.A.-K. and E.M. wrote the paper.

Conflicts of Interest: The authors declare no conflict of interest.

Appendix A. Years of DBH Measurement for the Different Plots

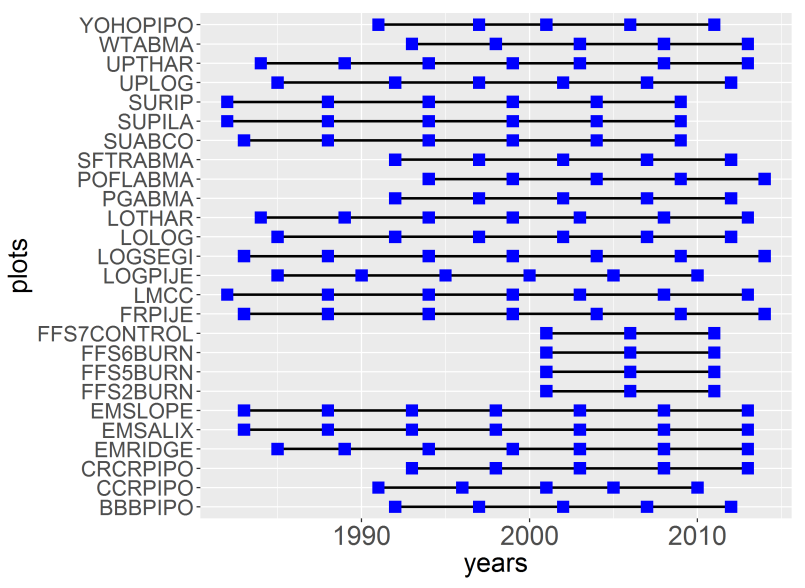

Figure A1. Years of DBH measurement for the different plots. 


\section{Appendix B. DIC Used for the Model Selection}

Table A1. DIC for models including no species-specific term or species-specific term for size or competition effect.

\begin{tabular}{ccc}
\hline No Species-Specific Term & Species-Specific Term for Size Effect & Species-Specific Term for Competition Effect \\
\hline 267598 & 273867 & 273907 \\
\hline
\end{tabular}

Table A2. DIC for models including each climate variables separately.

\begin{tabular}{cccccccc}
\hline AvTemp $_{t}$ & JanMin $_{t}$ & JulMax $_{t}$ & precip $_{t}$ & snow $_{t}$ & CWD $_{t}$ & AET $_{t}$ & ASpck $_{t}$ \\
273615 & 273014 & 273535 & 273149 & 272191 & 272984 & 272827 & 274591 \\
\hline AvTemp $_{t-1}$ & JanMin $_{t-1}$ & JulMax $_{t-1}$ & precip $_{t-1}$ & snow $_{t-1}$ & CWD $_{t-1}$ & AET $_{t-1}$ & ASpck $_{t-1}$ \\
271408 & 275333 & 273214 & 274070 & 273626 & 272997 & 274212 & 273046 \\
\hline AvTemp $_{d e v, t}$ & JanMin $_{d e v, t}$ & JulMax $_{d e v, t}$ & precip $_{d e v, t}$ & snow $_{d e v, t}$ & CWD $_{d e v, t}$ & AET $_{d e v, t}$ & ASpck $_{d e v, t}$ \\
272991 & 272411 & 273620 & 273252 & 273008 & 271669 & 273464 & 274833 \\
\hline AvTemp $_{d e v, t-1}$ & JanMin $_{d e v, t-1}$ & JulMax $_{d e v, t-1}$ & precip $_{d e v, t-1}$ & snow $_{d e v, t-1}$ & CWD $_{d e v, t-1}$ & AET $_{d e v, t-1}$ ASpck $_{d e v, t-1}$ \\
274132 & 273904 & 274560 & 273662 & 272365 & 272829 & 272870 & 272255 \\
\hline
\end{tabular}

\section{Appendix C. Results Table}

Table A3. Climate parameter estimated by a different model for each climate variable (model used for the selection). $95 \% \mathrm{CI}$ in brackets.

\begin{tabular}{|c|c|c|c|c|c|}
\hline & PIMO & PICO & ABMA & PIJE & ABCO \\
\hline \multirow{2}{*}{ AvTemp } & 0.0158 & -0.0555 & 0.0131 & 0.0455 & 0.00347 \\
\hline & {$[-0.0115 ; 0.0497]$} & {$[-0.0942 ;-0.0189]$} & {$[0.00606 ; 0.0183]$} & {$[0.0187 ; 0.0792]$} & [0.000897; 0.00681] \\
\hline \multirow{2}{*}{ JanMin } & 0.0124 & -0.0812 & 0.0023 & 0.0151 & 0.00339 \\
\hline & {$[-0.0125 ; 0.0433]$} & {$[-0.125 ;-0.0271]$} & {$[-0.00324 ; 0.00884]$} & {$[0.00701 ; 0.0287]$} & [0.00113; 0.00535] \\
\hline \multirow{2}{*}{ JulMax } & -0.00331 & -0.0317 & 0.0096 & -0.00594 & 0.000864 \\
\hline & {$[-0.0169 ; 0.0139]$} & {$[-0.0507 ;-0.00941]$} & {$[0.00552 ; 0.0129]$} & {$[-0.0204 ; 0.00741]$} & {$[-0.00133 ; 0.00375]$} \\
\hline precip & $\begin{array}{c}0.000159 \\
{[-8.62 \mathrm{e}-05 ; 0.000258]}\end{array}$ & $\begin{array}{c}-0.000119 \\
{[-0.000452 ; 0.000114]}\end{array}$ & $\begin{array}{c}-2.6 \mathrm{e}-05 \\
{[-8.94 \mathrm{e}-05 ; 5.75 \mathrm{e}-06]}\end{array}$ & $\begin{array}{c}8.43 e-05 \\
{[-6.69 e-05 ; 0.000216]}\end{array}$ & $\begin{array}{c}5.72 \mathrm{e}-05 \\
{[-0.000104 ; 8.86 \mathrm{e}-05]}\end{array}$ \\
\hline snow & $\begin{array}{c}0.000136 \\
{[-2.6 \mathrm{e}-05 ; 0.000255]}\end{array}$ & $\begin{array}{c}7.17 \mathrm{e}-05 \\
{[-0.000165 ; 0.000402]}\end{array}$ & $\begin{array}{c}-3.34 \mathrm{e}-05 \\
{[-0.000119 ;-4.76 \mathrm{e}-06]}\end{array}$ & $\begin{array}{c}1.45 \mathrm{e}-05 \\
{[-0.000219 ; 0.000158]}\end{array}$ & $\begin{array}{c}-1.15 \mathrm{e}-05 \\
{[-6.22 \mathrm{e}-05 ; 1.79 \mathrm{e}-05]}\end{array}$ \\
\hline CWD & $\begin{array}{c}0.000648 \\
{[0.000125 ; 0.00111]}\end{array}$ & $\begin{array}{c}-0.000732 \\
{[-0.0015 ;-5.2 \mathrm{e}-05]}\end{array}$ & $\begin{array}{c}0.000162 \\
{[7.11 \mathrm{e}-05 ; 0.00027]}\end{array}$ & $\begin{array}{c}0.000809 \\
{[0.000388 ; 0.00124]}\end{array}$ & $\begin{array}{c}-1.48 \mathrm{e}-05 \\
{[-7.05 \mathrm{e}-05 ; 0.000101]}\end{array}$ \\
\hline AET & $\begin{array}{c}-0.00104 \\
{[-0.00166 ;-0.000317]}\end{array}$ & $\begin{array}{c}-0.00111 \\
{[-0.00265 ; 0.000617]}\end{array}$ & $\begin{array}{c}0.000291 \\
{[0.000159 ; 0.000411]}\end{array}$ & $\begin{array}{c}0.000165 \\
{[-0.000298 ; 0.000618]}\end{array}$ & $\begin{array}{c}9.25 \mathrm{e}-05 \\
{[-0.000136 ; 0.000216]}\end{array}$ \\
\hline \multirow[t]{2}{*}{ ASpck } & $\begin{array}{c}0.000139 \\
{[-1.64 \mathrm{e}-05 ; 0.00027]}\end{array}$ & $\begin{array}{c}0.000179 \\
{[-5.3 \mathrm{e}-06 ; 0.000416]}\end{array}$ & $\begin{array}{c}-5.28 \mathrm{e}-05 \\
{[-8.56 \mathrm{e}-05 ;-2.03 \mathrm{e}-05]}\end{array}$ & $\begin{array}{c}-2.86 \mathrm{e}-05 \\
{[-0.00015 ; 8.55 \mathrm{e}-05]}\end{array}$ & $\begin{array}{c}1.99 \mathrm{e}-05 \\
{[-3.25 \mathrm{e}-05 ; 5.01 \mathrm{e}-05]}\end{array}$ \\
\hline & QUKE & QUCH & PILA & CADE & PIPO \\
\hline AvTemp & $\begin{array}{c}0.029 \\
{[0.0206 ; 0.0373]}\end{array}$ & $\begin{array}{c}-0.0675 \\
{[-0.191 ;-9.63 \mathrm{e}-05]}\end{array}$ & $\begin{array}{c}-0.00264 \\
{[-0.00723 ; 0.00343]}\end{array}$ & $\begin{array}{c}-0.00391 \\
{[-0.00805 ; 0.000868}\end{array}$ & $\begin{array}{c}-0.0496 \\
{[-0.0789 ;-0.0249]}\end{array}$ \\
\hline JanMin & $\begin{array}{c}0.0171 \\
{[0.00999 ; 0.0236]}\end{array}$ & $\begin{array}{c}-0.0683 \\
{[-0.122 ;-0.0127]}\end{array}$ & $\begin{array}{c}-0.00102 \\
{[-0.0047 ; 0.00364]}\end{array}$ & $\begin{array}{c}-0.00524 \\
{[-0.00779 ;-0.00296]}\end{array}$ & $\begin{array}{c}-0.0211 \\
{[-0.0332 ;-0.0104]}\end{array}$ \\
\hline JulMax & $\begin{array}{c}0.0309 \\
{[0.0234 ; 0.0383]}\end{array}$ & $\begin{array}{c}-0.0245 \\
{[-0.057 ; 0.0289]}\end{array}$ & $\begin{array}{c}-0.00185 \\
{[-0.00632 ; 0.00324]}\end{array}$ & $\begin{array}{c}0.000691 \\
{[-0.00211 ; 0.00485]}\end{array}$ & $\begin{array}{c}0.0224 \\
{[0.00389 ; 0.0401]}\end{array}$ \\
\hline precip & $\begin{array}{c}-0.000147 \\
{[-0.000279 ;-1.86 \mathrm{e}-05]}\end{array}$ & $\begin{array}{c}0.000489 \\
{[-0.000273 ; 0.00174]}\end{array}$ & $\begin{array}{c}-4.25 \mathrm{e}-05 \\
{[-0.000149 ; 2.55 \mathrm{e}-05]}\end{array}$ & $\begin{array}{c}7.07 \mathrm{e}-05 \\
{[3.22 \mathrm{e}-05 ; 0.000121]}\end{array}$ & $\begin{array}{c}8.25 \mathrm{e}-05 \\
{[-5.03 \mathrm{e}-05 ; 0.000211]}\end{array}$ \\
\hline snow & $\begin{array}{c}-0.00029 \\
{[-0.000378 ;-0.00021]}\end{array}$ & $\begin{array}{c}0.000445 \\
{[-0.000493 ; 0.00142]}\end{array}$ & $\begin{array}{c}1.31 \mathrm{e}-05 \\
{[-3.23 \mathrm{e}-05 ; 6.62 \mathrm{e}-05]}\end{array}$ & $\begin{array}{c}8.25 \mathrm{e}-05 \\
{[2.69 \mathrm{e}-05 ; 0.00012]}\end{array}$ & $\begin{array}{c}0.000375 \\
{[0.000125 ; 0.000523]}\end{array}$ \\
\hline CWD & $\begin{array}{c}0.000688 \\
{[0.000486 ; 0.000908]}\end{array}$ & $\begin{array}{c}0.000482 \\
{[-0.00109 ; 0.0017]}\end{array}$ & $\begin{array}{c}6.68 \mathrm{e}-06 \\
{[-0.000147 ; 0.000125]}\end{array}$ & $\begin{array}{c}-0.000106 \\
{[-0.000194 ;-8.26 \mathrm{e}-06]}\end{array}$ & $\begin{array}{c}-0.000107 \\
{[-0.000648 ; 0.000246]}\end{array}$ \\
\hline AET & $\begin{array}{c}0.000573 \\
{[0.000299 ; 0.000813]}\end{array}$ & $\begin{array}{c}-0.0035 \\
{[-0.00587 ;-0.000261]}\end{array}$ & $\begin{array}{c}-6.87 \mathrm{e}-05 \\
{[-0.000396 ; 0.000224]}\end{array}$ & $\begin{array}{c}-8.05 \mathrm{e}-05 \\
{[-0.000262 ; 0.000122]}\end{array}$ & $\begin{array}{c}-0.000664 \\
{[-0.00134 ; 0.000367]}\end{array}$ \\
\hline ASpck & $\begin{array}{c}-0.000232 \\
{[-0.000301 ;-0.000184]}\end{array}$ & $\begin{array}{c}7 \mathrm{e}-04 \\
{[-0.000601 ; 0.00172]}\end{array}$ & $\begin{array}{c}6.42 \mathrm{e}-05 \\
{[2.47 \mathrm{e}-06 ; 0.00013]}\end{array}$ & $\begin{array}{c}4 \mathrm{e}-05 \\
{[-1.57 \mathrm{e}-05 ; 8.83 \mathrm{e}-05]}\end{array}$ & $\begin{array}{c}0.000165 \\
{[-0.000484 ; 0.00073]}\end{array}$ \\
\hline
\end{tabular}


Table A3. Cont.

\begin{tabular}{|c|c|c|c|c|c|}
\hline & PIMO & PICO & ABMA & PIJE & ABCO \\
\hline \multirow{2}{*}{ AvTemp dev } & 0.167 & -0.0746 & -0.04 & 0.111 & -0.0243 \\
\hline & {$[0.0945 ; 0.251]$} & {$[-0.203 ; 0.04]$} & {$[-0.0694 ; 0.00358]$} & {$[0.0507 ; 0.183]$} & {$[-0.039 ; 0.0491]$} \\
\hline \multirow{2}{*}{ JanMin $_{d e v}$} & 0.0253 & -0.119 & -0.0248 & 0.0552 & 0.0154 \\
\hline & {$[-0.0166 ; 0.0619]$} & {$[-0.276 ;-0.00465]$} & {$[-0.0335 ;-0.0151]$} & {$[0.0185 ; 0.104]$} & {$[0.00463 ; 0.0371]$} \\
\hline \multirow{2}{*}{ JulMax $_{d e v}$} & -0.000347 & -0.000227 & 0.000272 & 0.0164 & -0.0114 \\
\hline & {$[-0.0301 ; 0.0181]$} & {$[-0.0384 ; 0.0584]$} & {$[-0.00631 ; 0.00923]$} & {$[-0.0155 ; 0.038]$} & {$[-0.0168 ;$} \\
\hline precip $_{d e v}$ & $\begin{array}{c}0.000116 \\
{[-0.00011 ; 0.000239]}\end{array}$ & $\begin{array}{c}-0.000137 \\
{[-0.000388 ; 3.6 \mathrm{e}-05]}\end{array}$ & $\begin{array}{c}1.79 e-05 \\
{[-6.48 e-05 ; 6.13 e-05]}\end{array}$ & $\begin{array}{c}5.27 \mathrm{e}-05 \\
{[-8.55 \mathrm{e}-05 ; 0.000243]}\end{array}$ & $\begin{array}{c}7.22 \mathrm{e}-05 \\
{[-4.92 \mathrm{e}-05 ; 9.68 \mathrm{e}-05]}\end{array}$ \\
\hline snow dev $_{\text {d }}$ & $\begin{array}{c}0.000153 \\
{[-4.56 \mathrm{e}-05 ; 0.000266]}\end{array}$ & $\begin{array}{c}-0.000204 \\
{[-0.000528 ; 3.72 \mathrm{e}-05]}\end{array}$ & $\begin{array}{c}3.76 \mathrm{e}-05 \\
{[2.78 \mathrm{e}-06 ; 6.93 \mathrm{e}-05]}\end{array}$ & $\begin{array}{c}5.03 \mathrm{e}-05 \\
{[-0.000171 ; 0.000225]}\end{array}$ & $\begin{array}{c}0.000117 \\
{[-0.000129 ; 0.000164]}\end{array}$ \\
\hline $\mathrm{CWD}_{d e v}$ & $\begin{array}{c}0.000756 \\
{[0.000247 ; 0.00149]}\end{array}$ & $\begin{array}{c}7.63 \mathrm{e}-06 \\
{[-0.000949 ; 0.0011]}\end{array}$ & $\begin{array}{c}-6.78 \mathrm{e}-05 \\
{[-0.000218 ; 0.000178]}\end{array}$ & $\begin{array}{c}0.00107 \\
{[0.00048 ; 0.00173]}\end{array}$ & $\begin{array}{c}-0.000314 \\
{[-4 \mathrm{e}-04 ; 0.000153]}\end{array}$ \\
\hline $\mathrm{AET}_{d e v}$ & $\begin{array}{c}-0.00084 \\
{[-0.00215 ; 0.000122]}\end{array}$ & $\begin{array}{c}-0.000601 \\
{[-0.00263 ; 0.00125]}\end{array}$ & $\begin{array}{c}4.53 \mathrm{e}-05 \\
{[-0.000353 ; 0.00026]}\end{array}$ & $\begin{array}{c}-0.000955 \\
{[-0.00221 ; 0.00043]}\end{array}$ & $\begin{array}{c}0.000366 \\
{[-6.78 \mathrm{e}-05 ; 0.000529]}\end{array}$ \\
\hline \multirow[t]{2}{*}{$\mathrm{ASpck}_{d e v}$} & $\begin{array}{c}0.000163 \\
{[2.88 \mathrm{e}-05 ; 0.000288]}\end{array}$ & $\begin{array}{c}-0.000172 \\
{[-0.000408 ; 2.26 \mathrm{e}-05]}\end{array}$ & $\begin{array}{c}-5.59 \mathrm{e}-06 \\
{[-0.000115 ; 3.44 \mathrm{e}-05]}\end{array}$ & $\begin{array}{c}1.48 \mathrm{e}-05 \\
{[-0.000146 ; 0.000153]}\end{array}$ & $\begin{array}{c}0.000136 \\
{[2.55 \mathrm{e}-05 ; 0.000172]}\end{array}$ \\
\hline & QUKE & QUCH & PILA & CADE & PIPO \\
\hline AvTemp $_{d e v}$ & $\begin{array}{c}-0.0172 \\
{[-0.0856 ; 0.0382]}\end{array}$ & $\begin{array}{c}-0.0614 \\
{[-0.268 ; 0.181]}\end{array}$ & $\begin{array}{c}-0.0136 \\
{[-0.0505 ; 0.0287]}\end{array}$ & $\begin{array}{c}-0.0602 \\
{[-0.0928 ;-0.0313]}\end{array}$ & $\begin{array}{c}-0.0821 \\
{[-0.173 ;-0.00601]}\end{array}$ \\
\hline $\operatorname{JanMin}_{d e v}$ & $\begin{array}{c}-0.00503 \\
{[-0.0321 ; 0.0147]}\end{array}$ & $\begin{array}{c}-0.0969 \\
{[-0.151 ;-0.0212]}\end{array}$ & $\begin{array}{c}0.00421 \\
{[-0.0157 ; 0.024]}\end{array}$ & $\begin{array}{c}-0.00732 \\
{[-0.0204 ; 0.00962]}\end{array}$ & $\begin{array}{c}0.00965 \\
{[-0.0377 ; 0.0672]}\end{array}$ \\
\hline JulMax $_{d e v}$ & $\begin{array}{c}0.00679 \\
{[-0.0167 ; 0.0246]}\end{array}$ & $\begin{array}{c}0.196 \\
{[0.0226 ; 0.304]}\end{array}$ & $\begin{array}{c}0.00109 \\
{[-0.00792 ; 0.0118]}\end{array}$ & $\begin{array}{c}-0.0229 \\
{[-0.0326 ;-0.0131]}\end{array}$ & $\begin{array}{c}-0.0179 \\
{[-0.0505 ; 0.00794]}\end{array}$ \\
\hline $\operatorname{precip}_{d e v}$ & $\begin{array}{c}0.000121 \\
{[-1.12 \mathrm{e}-05 ; 0.000242]}\end{array}$ & $\begin{array}{c}0.000138 \\
{[-0.000954 ; 0.000908]}\end{array}$ & $\begin{array}{c}5.75 \mathrm{e}-06 \\
{[-7.87 \mathrm{e}-05 ; 7.28 \mathrm{e}-05]}\end{array}$ & $\begin{array}{c}9 \mathrm{e}-05 \\
{[-1.41 \mathrm{e}-05 ; 0.000151]}\end{array}$ & $\begin{array}{c}0.000154 \\
{[8.18 \mathrm{e}-06 ; 0.000299]}\end{array}$ \\
\hline snow $_{d e v}$ & $\begin{array}{c}0.000176 \\
{[4.96 \mathrm{e}-06 ; 0.000359]}\end{array}$ & $\begin{array}{c}7.32 \mathrm{e}-05 \\
{[-0.00161 ; 0.00155]}\end{array}$ & $\begin{array}{c}-6.23 e-07 \\
{[-0.000124 ; 8.97 e-05]}\end{array}$ & $\begin{array}{c}0.000194 \\
{[0.000109 ; 0.000309]}\end{array}$ & $\begin{array}{c}0.00046 \\
{[3.22 \mathrm{e}-06 ; 0.000888]}\end{array}$ \\
\hline $\mathrm{CWD}_{d e v}$ & $\begin{array}{c}-0.000641 \\
{[-0.00114 ;-0.000298]}\end{array}$ & $\begin{array}{c}0.00263 \\
{[0.000957 ; 0.00414]}\end{array}$ & $\begin{array}{c}-0.000163 \\
{[-0.000396 ; 5.67 \mathrm{e}-05]}\end{array}$ & $\begin{array}{c}-0.000359 \\
{[-0.000538 ; 1.43 \mathrm{e}-05]}\end{array}$ & $\begin{array}{c}1.65 \mathrm{e}-05 \\
{[-0.00062 ; 0.000558]}\end{array}$ \\
\hline $\mathrm{AET}_{d e v}$ & $\begin{array}{c}0.00094 \\
{[0.000511 ; 0.00166]}\end{array}$ & $\begin{array}{c}-0.00372 \\
{[-0.00538 ;-0.000731]}\end{array}$ & $\begin{array}{c}9.91 \mathrm{e}-05 \\
{[-0.000321 ; 0.000502]}\end{array}$ & $\begin{array}{c}0.000385 \\
{[-5.43 e-06 ; 0.00055]}\end{array}$ & $\begin{array}{c}-0.000124 \\
{[-0.000849 ; 0.000662]}\end{array}$ \\
\hline $\mathrm{ASpck}_{d e v}$ & $\begin{array}{c}0.000154 \\
{[-2.76 \mathrm{e}-05 ; 0.000437]}\end{array}$ & $\begin{array}{c}-0.00164 \\
{[-0.00385 ; 0.000829]}\end{array}$ & $\begin{array}{c}9.45 \mathrm{e}-05 \\
{[-1.81 \mathrm{e}-05 ; 0.000201]}\end{array}$ & $\begin{array}{c}0.000127 \\
{[-7.33 \mathrm{e}-05 ; 0.000264]}\end{array}$ & $\begin{array}{c}-0.000313 \\
{[-0.00176 ; 0.000858]}\end{array}$ \\
\hline
\end{tabular}

Table A4. Climate parameter estimated by a different model for each climate variable from the previous water year (model used for the selection). 95\% CI in brackets.

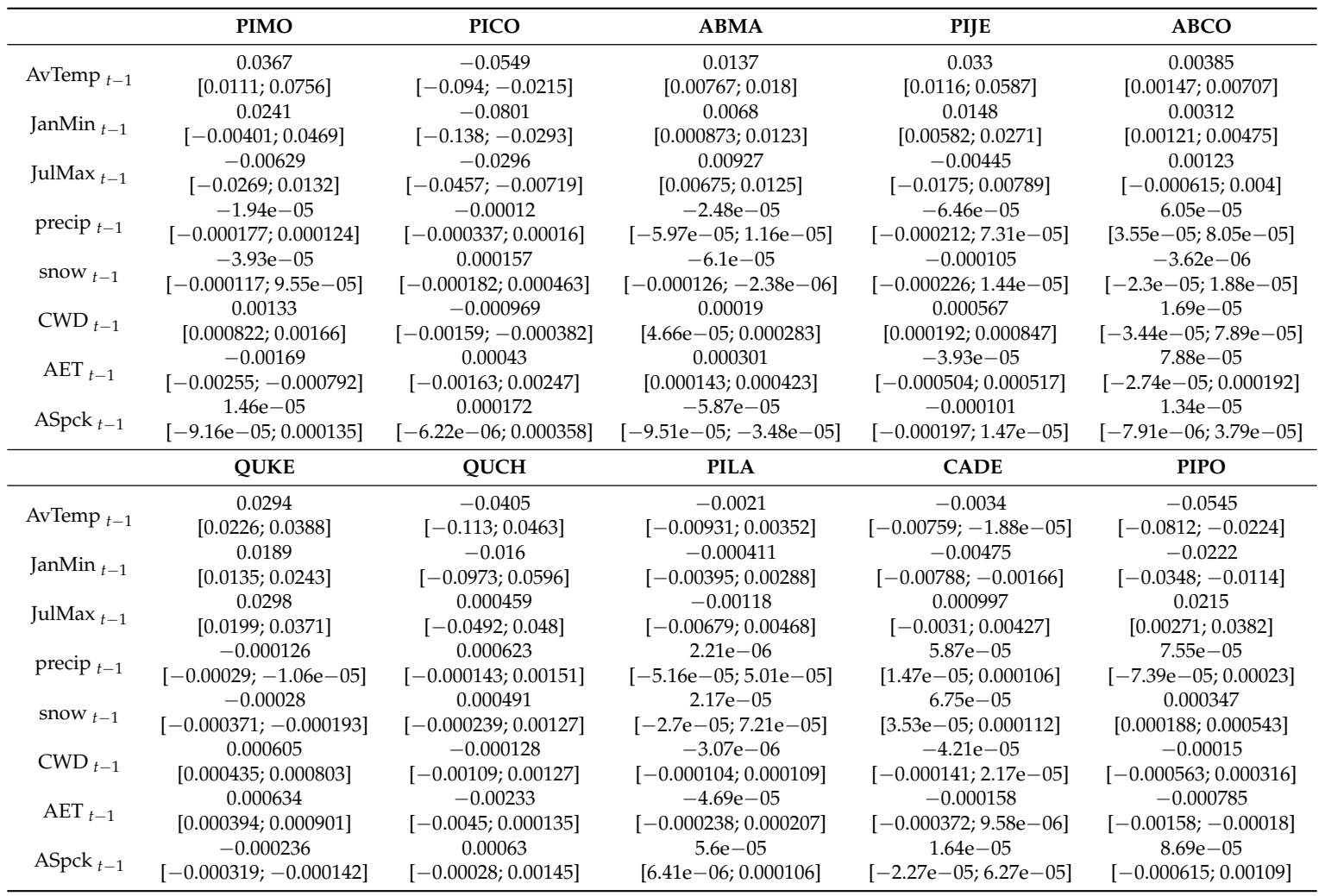


Table A4. Cont.

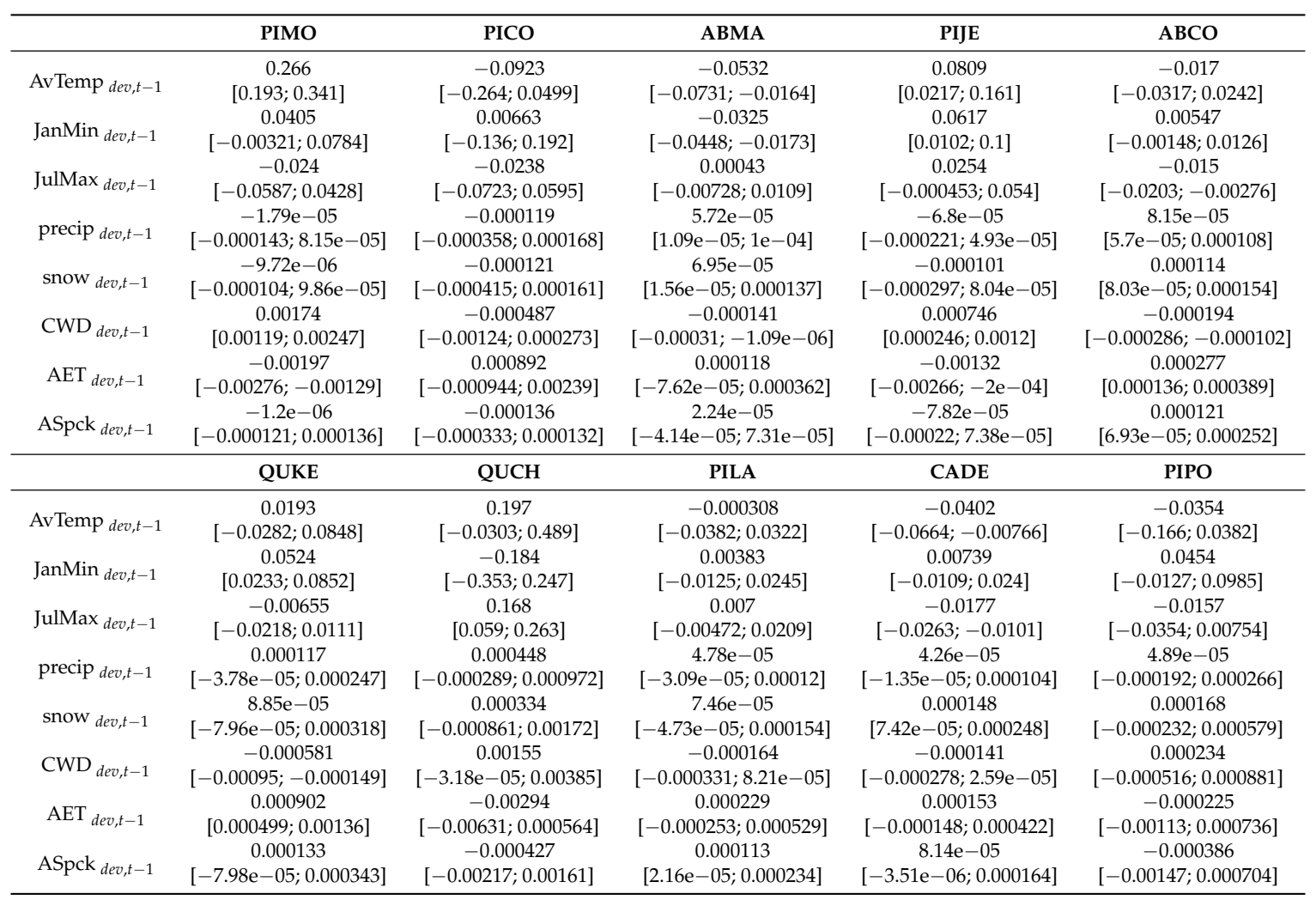

\section{Appendix D. Final Model}

Table A5. Parameter estimates for the final model including AvTemp of previous year, snow deviation of current year, precipitation of current year, and CWD deviation of previous year. $95 \% \mathrm{CI}$ in brackets.

\begin{tabular}{|c|c|c|c|c|c|}
\hline & $\begin{array}{c}\text { DBH } \\
\beta_{1}\end{array}$ & $\begin{array}{c}\text { Competition } \\
\qquad \beta_{2} \\
\end{array}$ & $\begin{array}{l}\text { Growth } \\
\text { Error } \\
\sigma_{\text {growth }}\end{array}$ & $\begin{array}{c}\text { Measurement } \\
\text { Error } \\
\sigma_{\text {obs }} \\
\end{array}$ & \\
\hline & $\begin{array}{c}0.00118 \\
{[0.00111 ; 0.00128]}\end{array}$ & $\begin{array}{c}-0.00119 \\
{[-0.00125 ;-0.0011]}\end{array}$ & $\begin{array}{c}0.752 \\
{[0.743 ; 0.76]}\end{array}$ & $\begin{array}{c}0.695 \\
{[0.678 ; 0.725]}\end{array}$ & \\
\hline $\begin{array}{c}\text { Species } \\
\mathrm{s}\end{array}$ & $\begin{array}{c}\text { Intercept } \\
\beta_{0, s}\end{array}$ & $\begin{array}{c}\operatorname{AvTemp}_{t-1} \\
\beta_{3, s}\end{array}$ & $\begin{array}{c}\text { Snow }_{d e v, t} \\
\beta_{4, s}\end{array}$ & $\begin{array}{c}\text { Precip }_{t} \\
\beta_{5, s}\end{array}$ & $\begin{array}{c}\mathrm{CWD}_{d e v, t-1} \\
\beta_{6, s}\end{array}$ \\
\hline PIMO & $\begin{array}{c}0.0597 \\
{[-0.87 ; 0.862]}\end{array}$ & $\begin{array}{c}0.00687 \\
{[-0.0295 ; 0.039]}\end{array}$ & $\begin{array}{c}2 \mathrm{e}-04 \\
{[-0.000449 ; 0.000802]}\end{array}$ & $\begin{array}{c}0.000148 \\
{[-0.000483 ; 0.000799]}\end{array}$ & $\begin{array}{c}0.00219 \\
{[0.00165 ; 0.0031]}\end{array}$ \\
\hline PICO & $\begin{array}{c}-0.46 \\
{[-2.34 ; 1.04]}\end{array}$ & $\begin{array}{c}-0.0394 \\
{[-0.0733 ;-0.00423]}\end{array}$ & $\begin{array}{c}-0.00108 \\
{[-0.00246 ; 0.00036]}\end{array}$ & $\begin{array}{c}0.000661 \\
{[-0.000335 ; 0.00204]}\end{array}$ & $\begin{array}{c}-0.000566 \\
{[-0.00176 ; 0.00114]}\end{array}$ \\
\hline ABMA & $\begin{array}{c}0.425 \\
{[0.327 ; 0.526]}\end{array}$ & $\begin{array}{c}0.0127 \\
{[0.00666 ; 0.0179]}\end{array}$ & $\begin{array}{c}0.000285 \\
{[0.000183 ; 0.000404]}\end{array}$ & $\begin{array}{c}-0.00018 \\
{[-0.000245 ;-0.000113]}\end{array}$ & $\begin{array}{c}-7.16 \mathrm{e}-05 \\
{[-0.000247 ; 0.000117]}\end{array}$ \\
\hline PIJE & $\begin{array}{c}-0.197 \\
{[-0.75 ; 0.308]}\end{array}$ & $\begin{array}{c}0.0112 \\
{[-0.0153 ; 0.0394]}\end{array}$ & $\begin{array}{c}-0.000189 \\
{[-0.000722 ; 0.000461]}\end{array}$ & $\begin{array}{c}0.000262 \\
{[-0.000221 ; 0.000697]}\end{array}$ & $\begin{array}{c}0.000663 \\
{[0.000128 ; 0.00119]}\end{array}$ \\
\hline $\mathrm{ABCO}$ & $\begin{array}{c}0.343 \\
{[0.249 ; 0.417]}\end{array}$ & $\begin{array}{c}0.00161 \\
{[-0.0018 ; 0.00482]}\end{array}$ & $\begin{array}{c}0.000145 \\
{[4.17 \mathrm{e}-05 ; 0.000238]}\end{array}$ & $\begin{array}{c}-4.92 \mathrm{e}-05 \\
{[-9.96 \mathrm{e}-05 ; 2.06 \mathrm{e}-05]}\end{array}$ & $\begin{array}{c}-0.000116 \\
{[-0.000223 ;-3.59 \mathrm{e}-05]}\end{array}$ \\
\hline QUKE & $\begin{array}{c}0.453 \\
{[0.159 ; 0.99]}\end{array}$ & $\begin{array}{c}0.0195 \\
{[0.00587 ; 0.0307]}\end{array}$ & $\begin{array}{c}0.000564 \\
{[0.000217 ; 0.0012]}\end{array}$ & $\begin{array}{c}-0.000387 \\
{[-0.000779 ;-0.000171]}\end{array}$ & $\begin{array}{c}-0.000171 \\
{[-0.000632 ; 0.00017]}\end{array}$ \\
\hline QUCH & $\begin{array}{c}2.18 \\
{[0.517 ; 4.57]}\end{array}$ & $\begin{array}{c}-0.103 \\
{[-0.221 ;-0.0119]}\end{array}$ & $\begin{array}{c}0.0027 \\
{[-0.000111 ; 0.00477]}\end{array}$ & $\begin{array}{c}-0.000904 \\
{[-0.00201 ; 0.00057]}\end{array}$ & $\begin{array}{c}0.00417 \\
{[0.00215 ; 0.00631]}\end{array}$ \\
\hline PILA & $\begin{array}{c}0.636 \\
{[0.446 ; 0.864]}\end{array}$ & $\begin{array}{c}-0.00686 \\
{[-0.0136 ;-0.00134]}\end{array}$ & $\begin{array}{c}0.000438 \\
{[0.000163 ; 0.000687]}\end{array}$ & $\begin{array}{c}-0.000274 \\
{[-0.000439 ;-0.000131]}\end{array}$ & $\begin{array}{c}-9.36 \mathrm{e}-05 \\
{[-0.000324 ; 0.00013]}\end{array}$ \\
\hline CADE & $\begin{array}{c}0.431 \\
{[0.324 ; 0.564]}\end{array}$ & $\begin{array}{c}-0.00732 \\
{[-0.0121 ;-0.00293]}\end{array}$ & $\begin{array}{c}0.000415 \\
{[0.000239 ; 0.000593]}\end{array}$ & $\begin{array}{c}-9.92 \mathrm{e}-05 \\
{[-0.000191 ;-2.17 \mathrm{e}-05]}\end{array}$ & $\begin{array}{c}1.75 \mathrm{e}-05 \\
{[-0.000148 ; 0.000191]}\end{array}$ \\
\hline PIPO & $\begin{array}{c}0.856 \\
{[0.416 ; 1.32]}\end{array}$ & $\begin{array}{c}-0.0498 \\
{[-0.0873 ;-0.0106]}\end{array}$ & $\begin{array}{c}0.000741 \\
{[-0.000162 ; 0.00203]}\end{array}$ & $\begin{array}{c}-0.000105 \\
{[-0.000457 ; 0.000188]}\end{array}$ & $\begin{array}{c}0.000528 \\
{[-0.000355 ; 0.00164]}\end{array}$ \\
\hline
\end{tabular}




\section{Appendix E. Effect of Different Climate on Growth for Common Species}

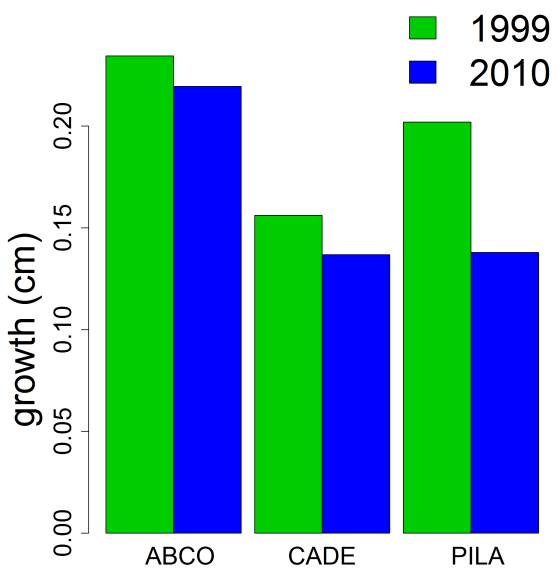

Figure A2. Example of simulated growth for three common species in YOHOPIPO during two distinct years: 1999 which was a dry year preceded by a wet year, and 2010 which was a wet year preceded by a dry year. Growth is computed using the final model and median values for diameter and competition.

\section{References}

1. Pederson, N.; Dyer, J.M.; Mcewan, R.W.; Hessl, A.E.; Mock, C.J.; Orwig, D.A.; Rieder, H.E.; Cook, B.I. The legacy of episodic climatic events in shaping temperate, broadleaf forests. Ecol. Monogr. 2014, 84, 599-620.

2. Fischlin, A.; Ayres, M.; Karnosky, D.; Kellomäki, S.; Louman, B.; Ong, C.; Plattner, C.; Santoso, H.; Thompson, I.; Booth, T.; et al. Future environmental impacts and vulnerabilities. Assessment 2009, 22, 53-100.

3. Choat, B.; Jansen, S.; Brodribb, T.J.; Cochard, H.; Delzon, S.; Bhaskar, R.; Bucci, S.J.; Feild, T.S.; Gleason, S.M.; Hacke, U.G.; et al. Global convergence in the vulnerability of forests to drought. Nature 2012, 491, 752-755.

4. Klos, R.J.; Wang, G.G.; Bauerle, W.L.; Rieck, J.R.; Los, R.; Ang, G.; Auerle, W.; Ieck, J. Drought impact on forest growth and mortality in the southeast USA: An analysis using Forest Health and Monitoring data. Ecol. Appl. 2009, 19, 699-708.

5. Kloeppel, B.D.; Clinton, B.D.; Vose, J.M.; Cooper, A.R. Drought Impacts on Tree Growth and Mortality of Southern Appalachian Forests. In Climate Variability and Ecosystem Response at Long-Term Ecological Research Sites; Number 686 m; Oxford University Press: New York, NY, USA, 2003; p. 459.

6. Fei, S.; Desprez, J.M.; Potter, K.M.; Jo, I.; Knott, J.A.; Oswalt, C.M. Divergence of species responses to climate change. Sci. Adv. 2017, doi:10.1126/sciadv.1603055.

7. IPCC. Summary for Policymakers; Cambeidge University Press: Cambeidge, UK, 2007; pp. 1-36.

8. Battles, J.J.; Robards, T.; Das, A.; Waring, K.; Gilless, J.K.; Biging, G.; Schurr, F. Climate change impacts on forest growth and tree mortality: A data-driven modeling study in the mixedconifer forest of the Sierra Nevada, California. Clim. Chang. 2008, 87, 193-213.

9. Koeppe, C.E.; Long, G.C.D. Weather and Climate; OSS Foundation: Los Angeles, CA, USA, 1958.

10. Rapacciuolo, G.; Maher, S.P.; Schneider, A.C.; Hammond, T.T.; Jabis, M.D.; Walsh, R.E.; Iknayan, K.J.; Walden, G.K.; Oldfather, M.F.; Ackerly, D.D.; et al. Beyond a warming fingerprint: Individualistic biogeographic responses to heterogeneous climate change in California. Glob. Chang. Biol. 2014, 20, 2841-2855.

11. Cook, E.R.; Seager, R.; Cane, M.A.; Stahle, D.W. North American Drought: Reconstructions, Causes, and Consequences. Earth-Sci. Rev. 2007, 81, 93-134.

12. Diffenbaugh, N.S.; Swain, D.L.; Touma, D. Anthropogenic warming has increased drought risk in California. Proc. Natl. Acad. Sci. USA 2015, 112, 3931-3936.

13. Pierce, D.W.; Das, T.; Cayan, D.R.; Maurer, E.P.; Miller, N.L.; Bao, Y.; Kanamitsu, M.; Yoshimura, K.; Snyder, M.A.; Sloan, L.C.; et al. Probabilistic estimates of future changes in California temperature and precipitation using statistical and dynamical downscaling. Clim. Dyn. 2013, 40, 839-856. 
14. Hayhoe, K.; Cayan, D.; Field, C.B.; Frumhoff, P.C.; Maurer, E.P.; Miller, N.L.; Moser, S.C.; Schneider, S.H.; Cahill, K.N.; Cleland, E.E.; et al. Emissions pathways, climate change, and impacts on California. Proc. Natl. Acad. Sci. USA 2004, 101, 12422-12427.

15. Pierce, D.W.; Cayan, D.R.; Das, T.; Maurer, E.P.; Miller, N.L.; Bao, Y.; Kanamitsu, M.; Yoshimura, K.; Snyder, M.A.; Sloan, L.C.; et al. The key role of heavy precipitation events in climate model disagreements of future annual precipitation changes in california. J. Clim. 2013, 26, 5879-5896.

16. Leung, L.R.; Qian, Y.; Bian, X.; Washington, W.M.; Han, J.; Roads, J.O. Mid-century ensemble regional climate change scenarios for the Western united States. Clim. Chang. 2004, 62, 75-113.

17. Vicuna, S.; Maurer, E.P.; Joyce, B.; Dracup, J.A.; Purkey, D. The Sensitivity of California Water Resources to Climate Change Scenarios1. JAWRA J. Am. Water Resour. Assoc. 2007, 43, 482-498.

18. Dracup, J.; Dracup, J.; Vicuna, S.; Vicuna, S. An Overview of Hydrology and Water Resources Studies on Climate Change: The California Experience. Change 2003, 82, 1-8.

19. Bonan, G.B. Forests and climate change: Forcings, feedbacks, and the climate benefits of forests. Science 2008, 320, 1444-1449.

20. Das, A.J.; Stephenson, N.L. Improving estimates of tree mortality probability using potential growth rate. Can. J. For. Res. 2015, 45, 920-928.

21. Wyckoff, P.H.; Clark, J.S. The relationship between growth and mortality for seven co-occurring tree species in the southern Appalachian Mountains. J. Ecol. 2002, 90, 604-615.

22. Van Mantgem, P.J.; Stephenson, N.L.; Mutch, L.S.; Johnson, V.G.; Esperanza, A.M.; Parsons, D.J. Growth rate predicts mortality of Abies concolor in both burned and unburned stands. Can. J. For. Res. 2003, 33, 1029-1038.

23. Das, A.J.; Battles, J.J.; Stephenson, N.L.; Mantgem, P.J.V.; van Mantgem, P.J. The relationship between tree growth patterns and likelihood of mortality: A study of two tree species in the Sierra Nevada. Can. J. For. Res. 2007, 37, 580-597.

24. Clark, J.S.; Iverson, L.; Woodall, C.W.; Allen, C.D.; Bell, D.M.; Bragg, D.C.; D’Amato, A.W.; Davis, F.W.; Hersh, M.H.; Ibanez, I.; et al. The impacts of increasing drought on forest dynamics, structure, and biodiversity in the United States. Glob. Chang. Biol. 2016, 22, 1-24.

25. Allen, C.D.; Macalady, A.K.; Chenchouni, H.; Bachelet, D.; McDowell, N.; Vennetier, M.; Kitzberger, T.; Rigling, A.; Breshears, D.D.; Hogg, E.H.T.; et al. A global overview of drought and heat-induced tree mortality reveals emerging climate change risks for forests. For. Ecol. Manag. 2010, 259, 660-684.

26. Yeh, H.Y.; Wensel, L.C. The relationship between tree diameter growth and climate for coniferous species in northern California. Can. J. For. Res. 2000, 30, 1463-1471.

27. Bales, R.C.; Goulden, M.L.; Hunsaker, C.T.; Conklin, M.H.; Hartsough, P.C.; O'Geen, A.T.; Hopmans, J.W.; Safeeq, M. Drought impacts on subsurface water storage, evapotranspiration and vegetation mortality in the southern Sierra Nevada, 2009-2015. J. Chem. Inf. Model. 2013, 53, 1689-1699.

28. Guarin, A.; Taylor, A.H. Drought triggered tree mortality in mixed conifer forests in Yosemite National Park, California, USA. For. Ecol. Manag. 2005, 218, 229-244.

29. Millar, C.I.; Westfall, R.D.; Delany, D.L. Response of high-elevation limber pine (Pinus flexilis) to multiyear droughts and 20th-century warming, Sierra Nevada, California, USA. Can. J. For. Res. 2007, 37, 2508-2520.

30. Itter, M.S.; Finley, A.O.; D'Amato, A.W.; Foster, J.R.; Bradford, J.B. Variable Effects of Climate on Forest Growth in Relation to Ecosystem State. Ecol. Appl. 2016, 27, 1082-1095.

31. Medvigy, D.; Wofsy, S.C.; Munger, J.W.; Moorcroft, P.R. Responses of terrestrial ecosystems and carbon budgets to current and future environmental variability. Proc. Natl. Acad. Sci. USA 2010, 107, 8275-8280.

32. Lenihan, J.M.; Drapek, R.; Bachelet, D.; Neilson, R.P. Climate Change Effects on Vegetation Distribution, Carbon, and Fire in California. Ecol. Appl. 2003, 13, 1667-1681.

33. Lenihan, J.M.; Bachelet, D.; Neilson, R.P.; Drapek, R. Response of vegetation distribution, ecosystem productivity, and fire to climate change scenarios for California. Clim. Chang. 2008, 87, 215-230.

34. Dymond, S.F.; D'Amato, A.W.; Kolka, R.K.; Bolstad, P.V.; Sebestyen, S.D.; Bradford, J.B. Growth-climate relationships across topographic gradients in the northern Great Lakes. Ecohydrology 2015, 929, 918-929.

35. Williams, A.P.; Seager, R. Temperature as a potent driver of regional forest drought stress and tree mortality. Nat. Clim. Chang. 2013, 3, 292-297.

36. Kunstler, G.; Albert, C.H.; Courbaud, B.; Lavergne, S.; Thuiller, W.; Vieilledent, G.; Zimmermann, N.E.; Coomes, D.A. Effects of competition on tree radial-growth vary in importance but not in intensity along climatic gradients. J. Ecol. 2011, 99, 300-312. 
37. Hurteau, M.; Zald, H.; North, M. Species-specific response to climate reconstruction in upper-elevation mixed-conifer forests of the western Sierra Nevada, California. Can. J. For. Res. 2007, 37, 1681-1691.

38. Potito, A.P.; Macdonald, G.M. The Effects of Aridity on Conifer Radial Growth, Recruitment, and Mortality Patterns in The Eastern Sierra Nevada, California. Arct. Antarct. Alpine Res. 2008, 40, 129-139.

39. Johnson, C.; Chhin, S.; Zhang, J. Effects of climate on competitive dynamics in mixed conifer forests of the Sierra Nevada. For. Ecol. Manag. 2017, 394, 1-12.

40. Das, A. The effect of size and competition on tree growth rate in old-growth coniferous forests. Can. J. For. Res. 2012, 42, 1983-1995.

41. Van Mantgem, P.; Das, A. An individual-based growth and competition model for coastal redwood forest restoration. Can. J. For. Res. 2014, 1057, 1-35.

42. Mérian, P.; Lebourgeois, F. Size-mediated climate-growth relationships in temperate forests: A multi-species analysis. For. Ecol. Manag. 2011, 261, 1382-1391.

43. Evans, M.E.; Falk, D.A.; Arizpe, A.; Swetnam, T.L.; Babst, F.; Holsinger, K.E. Fusing tree-ring and forest inventory data to infer influences on tree growth. Ecosphere 2017, 8, doi:10.1101/097535.

44. Eitzel, M.; Battles, J.; York, R.; Knape, J.; de Valpine, P. Estimating tree growth from complex forest monitoring data. Ecol. Appl. 2013, 23, 1288-1296.

45. Clark, J.S.; Wolosin, M.; Dietze, M.; Ibáñez, I.; LaDeau, S.; Welsh, M.; Kloeppel, B. Tree growth inference and prediction from diameter censuses and ring widths. Ecol. Appl. 2007, 17, 1942-1953.

46. Bowman, D.M.J.S.; Williamson, G.J.; Keenan, R.J.; Prior, L.D. A warmer world will reduce tree growth in evergreen broadleaf forests: Evidence from Australian temperate and subtropical eucalypt forests. Glob. Ecol. Biogeogr. 2014, 23, 925-934.

47. Flint, L.E.; Flint, A.L.; Thorne, J.H.; Boynton, R. Fine-scale hydrologic modeling for regional landscape applications: the California Basin Characterization Model development and performance. Ecol. Process. 2013, 2, 25.

48. Hegyi, F. A simulation model for managing jack-pine stands. In Growth Models for Tree and Stand Simulation; Fries, J., Ed.; Royal College of Music, Stockholm: Stockholm, Sweden, 1974; pp. 74-90.

49. Lorimer, C.G. Tests of age-independent competition indices for individual trees in natural hardwood stands. For. Ecol. Manag. 1983, 6, 343-360.

50. Coates, K.D.; Canham, C.D.; LePage, P.T. Above-versus below-ground competitive effects and responses of a guild of temperate tree species. J. Ecol. 2009, 97, 118-130.

51. Canham, C.D.; LePage, P.T.; Coates, K.D. A neighborhood analysis of canopy tree competition: Effects of shading versus crowding. Can. J. For. Res. 2004, 34, 778-787.

52. Contreras, M.A.; Affleck, D.; Chung, W. Evaluating tree competition indices as predictors of basal area increment in western Montana forests. For. Ecol. Manag. 2011, 262, 1939-1949.

53. Slack, A.W.; Kane, J.M.; Knapp, E.E.; Sherriff, R.L. Contrasting impacts of climate and competition on large sugar pine growth and defense in a fire-excluded forest of the central Sierra Nevada. Forests 2017, 8, 244.

54. Anderegg, W.R.L.; Schwalm, C.; Biondi, F.; Camarero, J.J.; Koch, G.; Litvak, M.; Ogle, K.; Shaw, J.D.; Shevliakova, E.; Williams, A.P.; et al. Pervasive drought legacies in forest ecosystems and their implications for carbon cycle models. Science 2015, 349, 528-532.

55. Virlouvet, L.; Fromm, M. Physiological and transcriptional memory in guard cells during repetitive dehydration stress. New Phytol. 2015, 205, 596-607.

56. R Core Team. R: A Language and Environment for Statistical Computing. In $R$ Foundation for Statistical Computing; R Core Team: Vienna, Austria, 2015.

57. Sturtz, S.; Ligges, U.; Gelman, A. R2WinBUGS: A Package for Running WinBUGS from R. J. Stat. Softw. 2005, 12, 1-16.

58. Bigelow, S.W.; Papaik, M.J.; Caum, C.; North, M.P. Faster growth in warmer winters for large trees in a Mediterranean-climate ecosystem. Clim. Chang. 2014, 123, 215-224.

59. Stephenson, N.L. Actual evapotranspiration and deficit: Biologically meaningful correlates of vegetation distribution across spatial scales. J. Biogeogr. 1998, 25, 855-870.

60. Stephenson, N.L. Climatic control of vegetation distribution: the role of the water balance. Nat. Am. 1990, 135, 649-670.

61. Niemelä, P.; Chapin, F.S.; Danell, K.; Bryant, J.P. Herbivory-mediated responses of selected boreal forests to climatic change. Clim. Chang. 2001, 48, 427-440. 
62. Bale, J.S.; Masters, G.J.; Hodkinson, I.D.; Awmack, C.; Bezemer, T.M.; Brown, V.K.; Butterfield, J.; Buse, A.; Coulson, J.C.; Farrar, J.; et al. Herbivory in global climate change research: Direct effects of rising temperature on insect herbivores. Glob. Chang. Biol. 2002, 8, 1-16.

63. Trân, J.K.; Ylioja, T.; Billings, R.F.; Régnière, J.; Ayres, M.P. Impact of minimum winter temperatures on the population dynamics of Dendroctonus frontalis. Ecol. Appl. 2007, 17, 882-899.

64. Hurteau, M.D.; Robards, T.A.; Stevens, D.; Saah, D.; North, M.; Koch, G.W. Modeling climate and fuel reduction impacts on mixed-conifer forest carbon stocks in the Sierra Nevada, California. For. Ecol. Manag. 2014, 315, 30-42.

65. D'Amato, A.W.; Bradford, J.B.; Fraver, S.; Palik, B.J. Effects of thinning on drought vulnerability and climate response in north temperate forest ecosystems. Ecol. Appl. 2013, 23, 1735-1742.

66. Maloney, P.E.; Smith, T.F.; Jensen, C.E.; Innes, J.; Rizzo, D.M.; North, M.P. Initial tree mortality and insect and pathogen response to fire and thinning restoration treatments in an old-growth mixed-conifer forest of the Sierra Nevada, California. Can. J. For. Res. 2008, 38, 3011-3020.

67. Van Mantgem, P.J.; Stephenson, N.L. Apparent climatically induced increase of tree mortality rates in a temperate forest. Ecol. Lett. 2007, 10,909-916.

68. Allen, C.D.; Breshears, D.D.; McDowell, N.G. On underestimation of global vulnerability to tree mortality and forest die-off from hotter drought in the Anthropocene. Ecosphere 2015, 6, 129.

69. Bigler, C. Trade-Offs between Growth Rate, Tree Size and Lifespan of Mountain Pine (Pinus montana) in the Swiss National Park. PLoS ONE 2016, doi:10.1371/journal.pone.0150402.

(C) 2017 by the authors. Licensee MDPI, Basel, Switzerland. This article is an open access article distributed under the terms and conditions of the Creative Commons Attribution (CC BY) license (http:/ / creativecommons.org/licenses/by/4.0/). 